\title{
Walter Schmithals: His contribution to the theological and historical interpretation of the New Testament
}

\author{
Author: \\ Piet B. Boshoff \\ Affiliation: \\ ${ }^{1}$ Reformed Theological \\ College, University of \\ Pretoria, South Africa \\ Note: \\ This article is a tribute to \\ Andries van Aarde and the \\ late Walter Schmithals, \\ emeritus professor at \\ the Humboldt University, \\ Berlin (Germany) and \\ member of the editorial \\ board of HTS Theological \\ Studies for 15 years. The \\ article is based on Dr P.B. \\ Boshoff's DD dissertation \\ at the University of \\ Pretora, with Prof. Dr \\ Andries G. van Aarde \\ as supervisor (and Prof \\ Dr G.M.M. Pelser as \\ co-supervisor), in close \\ collaboration of Professor \\ Scmhithals himself. \\ This doctoral thesis was \\ published as History \\ and Theology: Walter \\ Schmithals on the unity \\ of the New Testament, \\ Princeton Theological \\ Monograph Series 47, by \\ Pickwick Publications, San \\ Jose, California, in 2001. \\ Correspondence to: \\ Piet Boshoff \\ email: \\ pbboshoff@telkomsa.net \\ Postal address: \\ Lynnwood Road, Hatfield \\ 0083, Pretoria, South Africa \\ Dates: \\ Received: 03 July 2010 \\ Accepted: 10 July 2010 \\ Published: 07 June 2011 \\ How to cite this article: \\ Boshoff, P.B., 2011, \\ 'Walter Schmithals: \\ His contribution to the \\ theological and historical \\ interpretation of the New \\ Testament ', HTS Teologies \\ Studies/Theological Studies \\ 67(1), Art. \#780, 15 pages. \\ DOI: $10.4102 /$ hts.v67i1.780 \\ (C) 2011. The Authors. \\ Licensee: OpenJournals \\ Publishing. This work \\ is licensed under the \\ Creative Commons \\ Attribution License.
}

The aim of this article was to explain Walter Schmithals' unique understanding of the unity of the New Testament message. It focuses on his historical en theological interpretation of the New Testament within the parameters of the historical-critical paradigm. This article describes how Schmithals combines historical criticism with the core tenets of Protestant theology. The following facets were emphasised: Gnosticism, gospel studies and Q, Paul, early Christianity, emperor cult, separation from the synagogue, historical Jesus, apocalypticism, historical Jesus, the relationship between the Old and New Testament, ecclesiology and New Testament ethics.

\section{Introduction}

Schmithals (1971b:50; 1996:24) tells the story of how he accidentally attended Rudolf Bultmann's lectures. Having completed his studies at the theological school of Wuppertal, he travelled to the Philipps University at Marburg in March 1948 to complete his studies and obtain the necessary ecclesiastical recognition. He did not go to Marburg because of any acquaintance with Bultmann or for the reason that he wished to study under Bultmann. According to him, he, in fact, arrived there in spite of Bultmann. What drew him was the availability of lodgings at a former hunters' barracks.

Schmithals attended Bultmann's lectures on the theology of the New Testament, the history of the investigation of the life of Jesus and on the interpretation of 1 Corinthians and 2 Corinthians. He also took part in two seminar lectures directed by Bultmann on Pauline Theology in the 1948/1949-winter semester and on the Johannine epistles in the summer semester of 1949. Bultmann (1950) reported as follows: 'Herr Schmithals ist mir als Mitglied des neutestamentlichen Seminars in mehreren Semestern als ausgezeichnet begabt und als sehr fleissig bekannt'.

Because of the storm resulting from Bultmann's ideas on the demythologisation of the New Testament kerygma, a group was formed, which initially discussed exegetical problems in the light of existential interpretation and, later, works on dogmatic theology under the leadership of Bultmann on a monthly basis. Bultmann (1967:33) noted, with respect to Schmithals, that as a pastor, he made the effort to travel from Raumland to attend these gatherings and that later, as lecturer in Marburg, he became a tower of strength within this group.

Schmithals was fascinated by the fact that Bultmann treated the divine acts of salvation in Christ seriously and yet attempted to apply historical exegesis with a radical authenticity, making the Biblical and reformational dogma understandable by employing historical science.

Establishing the unity between historical and theological interpretation is regarded by Schmithals to be the task of the modern theologian. Historical consciousness came to the fore and theology should acknowledge this fully, whilst remaining faithful to the dogma. This is the only way in which theology today can today be seen as a reliable expression of the word of God. To me, he is more successful than Bultmann in making the subject matter of the New Testament accessible on a historical critical level. He describes in much greater detail the historical basis of the unity of historical and theological interpretation.

\section{Schmithals' debut: 'Die Gnosis in Korinth'}

In 1948/1949 Schmithals attended the lectures given by Bultmann on 1 and 2 Corinthians. These lectures awakened his interest in the Corinthian letters and in the gnostic antagonists with whom Paul had to contend in Corinth. He says that he later proposed to Bultmann that 'Die Gnosis in Korinth' [The Gnosis in Corinth] should be the title of his (Schmithals') thesis and that Bultmann enquired whether this would not be too limiting for a thesis. According to Bultmann, there was very little Gnosticism in Corinth and he proposed that Schmithals should rather use the title 'Die Gnosis im Neuen Testament' [The Gnosis in the New Testament]. Schmithals agreed, but resolved to retain 
his original title, as he suspected that Gnosticism exerted a much greater influence in Corinth. He decided to record the theology of Paul's gnostic antagonists in Corinth. Here, in persevering with his chosen theme, Schmithals displays the character of a researcher with his own originality.

In his report on the thesis, Bultmann wrote that Schmithals' work speaks of his uncommon powers of independent thought. Bultmann often experienced tension in following the precise exposition and strict train of thought. 'Im Blick auf die Energie und Originalität des Denkens und die Konsequenz der Gedankenführung könnte man versucht sein, die geradezu als glänzend zu bezeichnen' (Bultmann 1954). Although Bultmann was not in agreement with all the details, the end result convinced him. New light was shed on many texts and questions answered that were previously unanswerable. Bultmann proposed magna cum laude for the thesis.

Three German editions of 'Die Gnosis in Korinth' appeared. It was also published in English in 1971. Schmithals used the later editions to introduce corrections and additions to the text and to react to comments his work had elicited.

\section{Pointers in the theological understanding of the New Testament}

A serious need exists amongst students and other persons for a pointer in New Testament theology. The difficulty experienced in this area is clearly evident from Engelbrecht's (1982:59) compassionate remark: 'Blessed is also the exegete if he knows exactly what he is doing'. Themes that are related to this accountability also form the basis of the lectures that Schmithals presented over the years. By these means, the student is introduced to the history of the subject and the problems that have been experienced, as well as the solutions offered.

'New Testament' refers to historical documents that have to be interpreted through historical-critical exegesis. 'Theology' refers to the fact that the New Testament is God's Word. The historical documents are proof of the divine truth. The problems of New Testament theology are interwoven with the fact that a historical method is applied in order to formulate a dogmatic truth. In what follows, an outline is presented and terminological interpretations given of how Schmithals points the way to the theology of the New Testament. It is done with the conviction that these burning issues will force the reader to take part in the process. It is Schmithals' ideal to inspire theologising.

\section{The gospel}

According to the oldest textual witnesses in 1 Corinthians 2:1, Paul describes his kerygma or proclamation as 'the testimony about God': 'And when I came to you, brothers, I did not come with eloquence or words of wisdom as I proclaimed the testimony about God to you'. The description 'testimony about God' for that which Paul proclaims was not fixed, but could vary. In the old Greek manuscripts the variation 'God's mystery' appears. Schmithals (1982b:71) gains the impression that Paul did not, in fact, use a set expression to describe the 'divine truth', 'message of God' or 'religious testimony'. It is as if the old scribes knew that other terms could be used to refer to the same issue. Paul's proclaimed 'testimony about God' lays claim to the fact that it fulfils human expectations and provides the reason for existence. The 'divine testimony' is able to lead us to a comprehensive self-understanding. In addition, it is in support of this claim, Paul continues, that he proclaims Jesus Christ and him the crucified. A more common name for the declared Christian message is 'gospel'. It is the gospel that is proclaimed and the gospel that is believed. Schmithals (1976:145-146, 1979:99, 1988a:376) points out that although the message may be unfolded in a variety of ways, the gospel is focused on the one unifying truth (Mk 1:14-15):

After John was put in prison, Jesus went into Galilee, proclaiming the gospel of God. 'The time has come', he said. 'The kingdom of God is near. Repent and believe the gospel'.

'The time has come ... The kingdom of God is near', bears testimony to the sole content of the gospel.

From the previous, it can be deduced that the New Testament clearly focuses on a specific theme. This theme may be indicated by means of the words the 'gospel', the 'kerygma' or the 'Biblical dogma' and shows that which is the truly Christian, or the subject of the Christian confession and preaching. Schmithals (1972d:188-189) regards the expression of this theme as the task of theology.

\section{The historical critical method}

Schmithals is adamant that the church can only be church with a canon and a text. The church is a creation of the word and its sole purpose is to elucidate the message. In essence, theology is simply exegesis (Schmithals 1970a:51; cf. Bultmann 1975:272).

For the exegesis of the Bible text, Schmithals' point of view is that historical consciousness and historical thinking are part of the modern ideology. The modern historical school of thought must be taken into account. The message of the gospel must be discussed within and with the help of this way of thinking. This realisation is a precondition when using historical method. When applied to the exegesis of Bible texts, historical method implies that the distance between today and the time in which the text was written must be understood. In the first place the text is the word of humans, determined by specific circumstances and this word of humans must be understood by the people of today. 'Historical' in the term 'historical critical' describes the historical discrepancy between that time and today. The 'critical' in describing the method should be read as an accentuation of the 'historical' (Schmithals 1971b:55). Here 'critical' does not entail criticism. 'Critical' is used in the sense of distinguishing and it amounts to drawing a distinction between that time and today. Today's exegete is not the original receiver of the Bible text; consequently each text must be understood in its historical setting. It was only through historical thinking that people came to realise the 
hermeneutical problem, how past history can be understood in the present (Schmithals 1970a:53). What is the reality of history and how does it become real again today? The reality of the history of the New Testament is dogma. If understanding is to bridge the gap in time, the past reality must become real again. The potential for human existence in the past must become possible again. Hermeneutics as the science of translation takes on greater significance. The translation must be able to express my present understanding of the dogma, which the old text conveyed in the wording of its time (Schmithals 1972d:190).

The task of exegesis, in other words theology or hermeneutics, remains understanding nothing more. 'Understanding' means the understanding of the dogma, the message expressed in the old text. It is the dogma that claims authority and has to be understood. From the Christian point of view, people can only understand themselves from dogma. Understanding takes place in the present. I only understand here and now. Present understanding is the actual dogmatic understanding. This does not, as is widely accepted, take place in two stages, an understanding of the past, which is then transferred to the present reality. Present understanding of the historical exegesis must not be represented as if exegetes are entering the past darkness, where anything is to be expected and they must react to anything that they come across. In reality, the exegete is guided by their perspective. This perspective, which the exegete keeps in mind, is not another method in itself, but a hermeneutic guideline functioning within the framework of the historical-critical method (cf. Bultmann 1975:267-268). The exegete knows what to expect from the text. The texts of the New Testament suggest that they will be interrogated with the understanding of human existence in mind. More than one directive can be used within the historical method. Should the Bible wish to teach us concerning political realities or society, a sociological interpretation would be a suitable guideline for the exegesis?

Schmithals takes the existential interpretation as hermeneutic principle, because he is convinced that the Bible text expresses itself on human existence. Christian dogma is a pronouncement concerning human existence. Therefore, people only understand the Bible text to the extent that they understand themselves anew in it. Although the existential interpretation is not a method in itself, merely a guideline within the historical method, the exegesis of a Bible text by means of the historical-critical method depends on the good use made of this guideline. Without this directive there is no bridging of the gap between then and now. The charge that the historical method remains locked in the past and is not theologically productive is justified, unless the existential principle is applied. Existential interpretation does not prescribe to the text what it should say concerning its content; the text must be allowed to speak for itself. This is exactly what the historical critical method tries to ensure. The contribution made by the existential interpretation is that it makes one receptive to the ideas of the text on human existence. The correct question to be asked of the text is what it has to say on human existence. On the one hand, people are moved, by their existence, to the question of the possibility of understanding human existence. Human existence is incomplete and problematical; consequently, exegetes can approach the text with an openness of spirit to find clarity concerning their being (Bultmann 1975c:259; Schmithals 1967a:237). On the other hand, Christian dogma claims to be the expression of the theological truth of human existence. Dogma tells us what is happening between God and human beings. The readiness to listen, in other words, the problem of human existence, corresponds to the authority of the text. Where human existence is unproblematic, the text has no appeal. People are in search of themselves when they seek happiness, salvation and meaning. In this search for themselves, they go beyond themselves and seek God, because God is their salvation (Schmithals 1967a:243, 1970c:178).

Thus, the exegete is in a living relationship with the 'text', which is unfolded in the texts. The possibilities concerning human existence raised by the text are still possibilities for human existence today. Theologians are not interested in understanding the situation of those days or today as a situation in itself. Rather, they wish to understand the subject matter of the text within the context of life (Schmithals 1970a:54). In addition, this context changes continually. The satisfied person will ask the ancient question concerning God differently from the dissatisfied one and the student's question will differ from that of the professor. Human understanding of self is variable and must constantly be acquired anew in order to obtain an answer to this ancient question in the present time (Schmithals 1970c:176). Existential interpretation is not only appropriate because it can be linked to the meaning of the Christian dogma; it is also motivated because the purpose of the search for meaning is that people must reach an understanding of themselves. Understanding oneself is a precondition for all other understanding. It is only on this condition that one can understand the world and history, as well as one's neighbour and society, nature and culture.

Now the question arises: How does Schmithals see the relationship between faith and understanding? Does the Bible speak only to the believer? The answer is both yes and no. Yes, in the sense that the message of the Bible only comes into its own where it is also believed and I understand myself anew (Schmithals 1970a:25, 53, 1972d:188). Apart from the fact that understanding can coincide with faith (in the sense of understanding oneself), there is also the possibility of taking understanding to mean an effort to meditate on faith. Then it can be expressed in words and ideas, in other words, formulated scientifically. Now faith and understanding are no longer the same, but they constitute the relationship between believing existence and theology (Schmithals 1970b:84). To Schmithals, theology implies being scientifically active and achieving scientific results. He expects theologians to be able to defend their point of view scientifically (Schmithals 1967b:100; cf. Bultmann 1975c:273). According to Schmithals, theology is science in the true sense of the word. It is possible for theology to formulate the subject of its research concisely: Jesus Christ. Theology is not a science of comprehension or the humanities, but the science of a subject, the subject being the Biblical evidence concerning Jesus Christ (Schmithals 
1972d:188). This subject is examined scientifically by means of historical interpretation of the text. This requires critical rationality from exegetes in their elucidation of the text. It would not be incorrect to call theology a historical science, but Schmithals (1972d:190) prefers to describe it as a hermeneutical science. His reason is that in carrying through the process of understanding, the historically given Christ testimony fulfils its empirical critical function in the present. This is expressed in John 9:39: 'Jesus said, "For judgement I have come into this world, so that the blind will see and those who see will become blind"' (cf. Schmithals 1972d:191). Furthermore, Schmithals (1972d:192) understands theology as an ecclesiastical science, in other words, it is a function that has to be fulfilled by the church, which is faithful to its calling in constantly looking to its foundation and constantly being ready for its task. In the same way, technical society requires modern physics to maintain itself and keep on track. This implies that theological work must culminate in proclaiming, that historical critical exegesis must lead to sermons, because the church is created by the word.

According to the list of lectures given at the University of Marburg during the winter semester 1964/1965, Walter Schmithals took it upon himself to lecture on the exegesis of certain prescribed pericopes for sermons. This was his way of replying to the normal complaints and questions and implied criticism of theological students. They wanted to know 'Of what practical use are all the exercises in historical critical method to us in the church?' In the next semester he was joined by his Old Testament colleague, A.H.J. Gunneweg, for a study group on exegesis and preaching. After leaving Marburg, Schmithals to Berlin and Gunneweg to Bonn, they continued with this process, meeting regularly with students to carry into effect what may be called the way from exegesis to preaching. The 47th and last meeting took place in Bonn from 08 to 10 July 1988. Usually four texts were taken, two from the Old and two from the New Testament. These texts were explained and then either Schmithals or Gunneweg delivered a sermon in a church service. In the final discussion the group could mull over the 'way' which had been followed (cf. Schmithals 1992b:10).

The method used by Schmithals and Gunneweg was to lead the students into a process of understanding, in which the text is really understood and could lead to an understandable sermon. There is no better way of demonstrating that historical critical exegesis is useful and necessary in the task of preaching the gospel.

What students ask of their professors is whether they can preach the way they think theologically. Is there a natural transition from theology to preaching? What makes the question urgent is the impression that there is a vast gap between the results of historical exegesis and the preaching on Sundays. Sermons come from elsewhere, not from exegesis. Schmithals committed himself to historical exegesis as the only method in keeping with modern perceptions. It is worth walking a mile with Schmithals, because he concentrates on showing that exegesis must be done with a view to preaching and that it leads to the very doorstep of the sermon.

The fact that theology should lead to proclamation does not mean that a sermon must be produced willy-nilly, but presumes that the texts lend themselves to sermons in order to do them justice. As far as the relationship between faith and understanding is concerned, for Schmithals preaching must be classified as scientific understanding. His pastoral compassion urges him to distinguish between understanding, on the one hand and believing the content of the Christian message on the other (cf. Schmithals 1970b:84-85). When preaching, he wishes to arouse faith by his sermon, but what he does in the concrete circumstances is, at best, to get an understanding going of what faith is and what it does. That this understanding eventually becomes faith is no longer the responsibility of the preacher, but is donum Spiritus Sancti (the gift of the Holy Spirit). In the sermon itself we find existentials or objectifying understanding, but what the sermon achieves is existentiel or subjective understanding. Existentiel understanding is real understanding, where understanding has become agreement. Seen in this light, faith and understanding cannot be distinguished quantitatively, because the one who understands what faith is and does not believe, knows what he or she is doing in rejecting faith. Faith and understanding are quantitatively equal. Both have the same amount of insight. Faith does not have more knowledge than understanding. One can distinguish between faith and understanding as far as quality is concerned, the one who understands can repudiate faith, whilst someone else accepts it. It can also happen that one who repudiates it at first, subsequently understands himself or herself better through faith. Paul is a good example of one who became familiar and developed a living relationship with that which he at first persecuted but later proclaimed (cf. Schmithals 1978:391).

'Ecclesiastical' in the expression 'theology as ecclesiastical science' does not mean that the church and theology do not serve the world. The service rendered to the world by the servant is to bear witness to the Christ event. However, this service can only be rendered for as long as theology remains ecclesiastical science and is constantly busy confirming the authority of the church. This must not be understood theoretically, but should be practised in the true sense of the word. That is exactly what the historical method teaches: confirmation of the authority of the church only takes place when the message is proclaimed in understandable language to real people. The old text must be made understandable in the present (Schmithals 1967b:98). Understanding precedes faith. The unbeliever must be able to understand the contents of the Gospel. It is in the interest of the Gospel itself to be easily understood by unbelievers, because how can preaching change unbelievers into believers if it is not understood in the world of unbelief (Schmithals 1970b:84-85)?

Schmithals (1967b:97) stresses the fact that the Gospel is proclaimed, not some or other theology. The preacher who tries to motivate the congregation to accept objective saving facts as the truth, or one who presents results of historical Biblical science, has not yet proclaimed the Gospel. A detailed 
historical analysis still contains no message. A congregation does not benefit from theological information. Even literary analysis does not mean anything. The proclamation of the Gospel must always be new, always different and yet the same. Making the theological tradition real, by means of the historical-critical method, does not mean that dogmatic themes are of no importance to the exegete. On the contrary, one could describe Schmithals as an authority on dogmatics and he himself says that he learnt dogmatics from Bultmann (cf. Schmithals 1971b:56). One realises that Luther is the constant interlocutor of Schmithals. The large number of assenting references to Luther typifies his commentary on Mark. As far as method is concerned, Schmithals did not learn from Luther, because the latter reached his conclusions by prehistoric thinking, in terms of which the past and the present coalesce. This unhistorical method does not distinguish between long ago and today. Despite using a different method, Luther was still occupied with the same subject matter, the same dogma: Jesus Christ; only faith. Luther tried to understand the dogma of the church by means of his methodical modus operandi and in his time he succeeded in a most exemplary manner.

The meaning of the text is not established beforehand by the teachings of dogmatics. The dogmatic expectation with which the exegete approaches the text serve as a preconception what the text says and how the text should be questioned. Although it constitutes a preconceived idea, it is not unimportant. The exegete cannot approach the text without something specific in mind or with any kind of question; the question must be applicable and should be raised responsibly (Schmithals 1971a:38). When it comes to understanding this tradition, one cannot afford to ignore Luther or any other worthy theologian in the dogmatic tradition. The answers that they obtained regarding salvation, sin and happiness form part of the methodical equipment of the historical exegete. Exegetes are helped by the history of church, dogma and theology. It enables them to acquire their preconceived ideas responsibly (Schmithals 1971b:60).

The existential relationship to the substance of the text is necessary for understanding the text at all. Moreover, this existential understanding is explained in the preconception. Because of this preconception, the exegete can grasp what the text says concerning salvation. It is necessary to explain this preconception, in order for it to become clear what the questioning of the text is aiming at. The questioning must be done systematically so that the preconception can be strengthened, corrected or abandoned. An example of one of Luther's ideas that Schmithals corrected by means of the text, was the reformer's simul iustus, simul peccator (both justified and sinner). Schmithals (1980b:119-120, cf. 1988a:275) is of the opinion that Paul does not imply a duality in the redeemed. On no account does it mean growing sanctification, in which the redeemed struggles against themselves until the battle is won. The formula totus iustus, totus peccator is a better indication of Paul's intent. When seen as the 'old human being' of the old dispensation, someone is still a complete sinner; but seen as the 'new creation' of the new dispensation, someone is totally justified.
Preconception must not be confused with prejudice. Unlike a preconception, a prejudice is never put to the test, but is taken as final understanding. The understanding, obtained with the help of preconception by means of exegesis, becomes preconception for further understanding, because exegetes never reach a point where they know everything and become a spectator in relation to the saving act of God (cf. Schmithals 1967a:238-239). In preaching, preachers presume their listeners to have a preconception of the subject matter of the text. They often encounter prejudice amongst their listeners. They tie in with ideas that the listeners may have. For example, the listeners might understand conversion in relation to their moralising sense of sin, as being an improvement people can achieve in themselves. From the redemption in Christ, preachers tie in with this representation, so that they can contradict it in their explanation that the salvation of the human being begins with God and all human renown is excluded (cf. Schmithals 1953:534-536).

The generally held opinion is that dogmatics follows on exegesis. For example, Boers (1979:87) states: 'after that, one could perform the dogmatic task of interpreting the subject matter of the New Testament discerned in this way in doctrines that are relevant for the present'. Schmithals sees dogma and exegesis as moving in a circle. According to his view, the entrance to the circle is the expectation that the redemption of the sinner is the matter to be discussed in the text. If the text is approached from different angles, using other questions, it is a futile effort to try to reach the dogma after the exegesis has been done (cf. Bultmann 1975c:277). Rather, theological work consists of presupposing the dogma, understanding it as the subject matter of the text. In other words, to allow the questioning of the text to be guided by the dogma and in the process, to put it into words for today. The preconception of the dogma expresses the fact that the word has been given and salvation has come. The subject of theological research is both dogmatical and historical: the Biblical evidence concerning Christ (Schmithals 1971b:59). The advantage of the existential interpretation is that it unites the historical and dogmatical interpretations. Dogmatics becomes the methodical preconception of historical-critical theology and thus the unity of theology can be seen. The purpose of historical exegesis is not to compile points of doctrine, but to understand the text in actu. The process of understanding is still an adventure. The intrinsic value of Schmithals' work lies in the fact that he, in carrying out his theological task, has succeeded in unifying theology in an exemplary manner. This is no mean accomplishment, considering the fact that the historical and theological interpretations of most theologians diverge. Professors are usually specialists on their subject and the task of unifying theology is left to the student. In this way students are expected to achieve something professors have given up on, a fact that is very conveniently disregarded (Schmithals 1971b:60-61, 1996:43-44).

Schmithals (1967b:101) also noticed that ministers were not using their training in historical method in practice. They use other methods when preparing the Sunday sermon. He compares these preachers to pilots who cannot cope with the complicated technical apparatus of their machines and then 
decide to earn their living as taxi drivers. This state of affairs can satisfy no one. So Schmithals asks whether the historical method is really so difficult. If this is so, ministers should be trained in other methods, so that the tremendous gap between training and practice can be overcome. Perhaps the problem is that the historical method is not taught correctly. This should receive serious attention. Even if other methods are introduced, the best use must still be made of the historical method (Schmithals 1967b:101). From this exposition, it is also clear that Schmithals had a definite concept as to what should be studied in historical theology. This encyclopaedia should include an explanation of the present theological situation. From the history of historical exegesis, theology can account for the fact that the subjects Old Testament, New Testament, Church History and the History of Dogma have become distinct from Dogmatic Theology. Together these subjects, always associated with practical theology, form the system of historical theology. This interdependence should be maintained (Schmithals 1971b:60). A thorough introduction to hermeneutics should be given. The old rules of hermeneutics are no longer adequate. The problem of historical-critical exegesis must be spelt out: 'How can the reality of the past be made relevant in the present?'. Responsibility must be taken for the hermeneutical principle: 'What is our perspective regarding the Bible text?'. The objective and subjective elements in interpretation must be clarified:

- What is theology?

- What is preaching?

- What is preconception?

- What is existential understanding?

- What is scientific understanding?

For historical theology to abandon the dogmatic work done through the ages would be wrong. The history of the church and dogma, especially with reference to the theology of the Reformation, is necessary for the preconception of the Biblical dogma. The fact that the word 'history' is mentioned in theological, ecclesiastical and dogmatic history emphasises the fact that the message is always proclaimed temporarily. With regard to method, these disciplines find themselves in the same situation as exegesis. They should all apply hermeneutics as the science of translation (Schmithals 1971b:60). Schmithals (1971b:60) refers to so-called Practical Theology. It is called practical, although in reality it studies the many theories of service in the church. Practical Theology explains how the message can be made understandable in preaching, dogma and ministry. Although exegesis tries to penetrate to the heart of theology, where preaching becomes a possibility, the detail of preaching, dogma and ministry must not be underestimated. The manifold theories concerning ecclesiastical service include everything that has to be done: ethics, liturgiology, ecumenics and missionary work.

Schmithals (1974:82) feels that there is no other subject in the arts, which gives as wide and scientifically based training as a well-directed study of theology. It relates to the content of the study: Jesus Christ. To understand him does not mean merely to take note of a snippet of human history and experience. To understand him means to see history itself moving as a whole towards and from him. The one subject of theology cannot therefore be understood without many other connections. Theologians need philology to understand the testimonies of faith; they need the historical sciences to express the old words as new today; they learn from philosophers, poets and authors which questions they should answer. Psychology and sociology teach them about people and the world. Because they have to deal with everyday occurrences, they take note of what the behavioural sciences have to say.

There is no room for dogmatic theology in the system of historical theology, because Schmithals feels that dogmatic theology works according to its own, unhistorical method. Both historical and unhistorical methods are occupied with Biblical dogma. Between them there is no possibility of division of labour. One reaches its goal in one way and the other the same goal in a different way. They are in competition (Schmithals 1971b:61, 1996:52). Dogmatic theology must look after its own encyclopaedic arrangement of its subjects. In his essay, Barth, Bultmann und wir, Schmithals (1971b) pleads for the acknowledgement of the methodical distinction between dogmatic and historical theology. Revisions and adjustments to theological syllabuses will not bring the required clarity for students and lecturers. One way, or the other, will make becoming a theologian possible for anyone. No one becomes a theologian in two ways. No one has yet been able to reconcile the historical with the dogmatic method of working. Anyone trying it is sure to fail. This does not mean that there is no commonality. Historian and dogmatist meet when they reach their final goal. Schmithals (1971b:52, 1996:35) tells how Bultmann, after having read Barth's dogmatics painstakingly, sighed and remarked: 'Yes, this is all very well, but one cannot express it in this way'. This remark shows that Barth and Bultmann did not differ fundamentally, only regarding the method used.

\section{Comparative exegesis}

Schmithals could succeed in giving a noteworthy example of comparative exegesis by describing the united front of Paul's gnostic opponents, together with a historic reconstruction of the events. Although differing from the dominant trend in modern research, Schmithals is of the opinion (as was F.C. Baur) that Paul had to do with a single group of opponents and not with different groups. He differed from Baur in identifying this group, not as Judaistic Christians, but as Gnostics. According to Schmithals (1965a:132, 1984a:87) the gnostic apostles did their missionary work in the footsteps of Paul in Galatia, Philippi, Thessalonica and Corinth. During his so-called third missionary journey, Paul joined issue with these false apostles, who were trying to hijack the churches he had established (Schmithals 1965b:185).

In his struggle with the Gnostics, Paul insisted that leadership in the church be respected. In 1 Corinthians 16:15-18, Philippians 2:29 and Galatians 6:6 he asks this and in the letter to the people of Thessalonica it reads:

Now we ask you, brothers, to respect those who work hard amongst you, who have authority over you in the Lord and who admonish you. Hold them in the highest regard in love because of their work. Live in peace with each other.

(1 Th 5:12-13) 
Schmithals (1965b:122) points out that these admonishments had become typical in the later church in its anti-gnostic struggle. To the freedom of the pneumatics and the unrestricted revelation of the pneuma, the church opposes the teaching handed down and the minister. The apostolic tradition and the ecclesiastical office gave the church the victory over the Gnostics.

\section{Early Christianity}

Schmithals (1978:413, 1984b:154-155, 1994:86) thinks that Palestinian Jewish Christianity (Judaistic) developed simultaneously in two directions, namely Hellenistic Jewish Christianity or Hellenistic synagogical Christianity (Hellenistic) and purely universalistic Christianity (gnostic). Hellenistic Jewish Christianity was based in Antioch and is the relative continuation of Palestinian early Christianity (Schmithals 1984b:154). Unlike universalistic Christianity, the Antiochene point of view did not represent a thoroughgoing universalism. Their interpretation of the law, however, was not judaistic either. Mark 7 can serve as an example where we clearly see the theology of Antioch:

Jesus left that place and went to the vicinity of Tyre. He entered a house and did not want anyone to know it; yet he could not keep his presence secret. In fact, as soon as she heard about him, a woman whose little daughter was possessed by an evil spirit, came and fell at his feet. The woman was a Greek, born in Syrian Phoenicia. She begged Jesus to drive the demon out of her daughter. 'First let the children eat all they want' he told her, 'for it is not right to take the children's bread and toss it to their dogs'. 'Yes, Lord', she replied, 'but even the dogs under the table eat the children's crumbs'. Then he told her: 'For such a reply, you may go; the demon has left your daughter'. She went home and found her child lying on the bed and the demon gone.

(Mk 7:24-30)

The theme of this passage is Jesus and the gentiles' salvation coming from the Jews to the world.

Schmithals (1979:354) explains that the word 'first' in the passage 'first let the children eat all they want', promises a later time when the dogs will get their share. 'Dog' is the Jewish abusive word for gentile. Jesus expects the woman to realise that the Jews have precedence and that the gentiles will follow after. Gentiles have no claim to salvation; they received it undeservedly. At the same time, there is a warning to the gentile Christians against pride. Christians from the gentiles are not the only ones who can lay claim to God's grace. God has not rejected his people (Schmithals 1979:351-356). This Antiochene point of view does not represent a thoroughgoing universalism, but rather concerns the admission of a few uncircumcised people into the church (Schmithals 1978:401).

Schmithals (1978:413) locates universalistic Christianity in Damascus. After his conversion, Paul became convinced that he had persecuted people so violently for what was in fact the truth. Christ is the end of the law. As a Jew, Paul now relinquishes his obedience to the law. Here we do not find a practical or theoretical mitigation of the law, as in the Antiochene tradition, but a basic antinomy, where the principle of Jewish privilege is denied. There is no longer any distinction between Jew and gentile, therefore a law drawing this distinction is no longer valid (Schmithals 1978:400, 1982a:64, 1989:239). In Galatians 3:28 Paul quotes a doctrinal formula from this theology: 'There is neither Jew nor Greek, slave nor free, male nor female, for you are all one in Christ'. This is clearly the language of gnostic dualism. To the dualistic way of thinking, earthly differences lie only in the corporeal. The divine pneuma is above the mundane and not affected by the difference between man and woman, slave or free man, or between nations, race or language. Universalism, a basic idea of Gnosticism, was adopted and incorporated into Christianity. As members of the church of grace, in faith, man and woman, slave and freeman, Jew and Gentile are equal, although the natural and sociological differences still exist (Schmithals 1978:401).

In reply to the question of how a universalistic Christendom could have developed so early (a fact that is accepted by other researchers cf. Cadbury 1933:70, footnote 1) Schmithals maintains (1984b:156, 1989:241, cf. 1978:406, 1994:84-85) that it could be explained in theological history by the meeting of the 'Hellenists' (amongst whom Stephen played a leading role) and gnostic Jewry in Samaria, to which the name of Simon Magus is linked. In this meeting a branch of missionary Palestinian Jewish Christianity was able to christianise gnostic dualism by translating the substantial dualism into decisive dualism. 'Johannine theology' that is the theology of the fundamental gospel and the gospel, is rooted in universal Christianity (Schmithals 1992a:149).

\section{Q and Q1}

The symbol $Q$ denotes the hypothetical collection of Jesus' sayings or logia. This is the second of the two sources regarded as common to the Gospels of Matthew and Luke. In addition, it furnishes the foundation for work on the Synoptic Gospels. Schmithals writes his own literary history of $Q$ and in the process he clarifies historic relationships.

Schmithals (1979:23, 1985:384-404) invokes the scientific consensus that in $\mathrm{Q}$ an older tradition should be distinguished from a more recent edited version of the tradition. He identifies the older tradition, Q1 (Schmithals 1980a:51, 1982c:622, 1985:399-400, 1994:29, 47), as being a document of a prophetic-apocalyptic group, who were expecting the last days. Jesus and John were considered to be the prophets of the end-time. The turning point is John and Jesus continues his work. With the advent of the Son of Man, God's kingdom will have reached its goal. Later on, the Apostolic Fathers reported the continued existence of such a group, the Ebionites. According to the Fathers, they did not belong to the church, because they considered Jesus to be an ordinary human being. They denied his divinity and his status as Son of God. Schmithals (1979:52) is convinced that these followers of Jesus lived in Galilee. Later on, Schmithals (2001:41) modified the identification of this group to a 'messianic' group and perhaps made it more acceptable with his latest designation as 'Täufergemeinde', the disciple group of John the Baptist and adherents (Schmithals 2008:373).

In this unkerygmatic prophetic tradition of Jesus of the Q1 
Church, Jesus is placed on a par with John the Baptist:

To what then can I compare the children of this generation? What are they like? They are like children sitting in die market place and calling out to each other: 'We played the flute for you and you did not dance; we sang a dirge and you did not cry'. For when John the Baptist came neither eating bread nor drinking wine, you say 'He has a demon'. The Son of Man came eating and drinking and you say 'Here is a glutton and a drunkard, a friend of tax collectors and sinners'.

(Lk 7:31-34)

Schmithals (1980a:97-98) is of the opinion that the original Q document read 'Jesus' instead of 'Son of Man', thus placing Jesus on a par with John. The title 'Son of Man' was not originally a kerygmatic title given to Jesus. It was the designation of the celestial being, who would be the judge when the Old World came to an end. Thus the quoted passage (Lk 7:31-34) is a kerygmatic version of an unkerygmatic text. Here Jesus is identified as the eschatological judge, the Son of Man, because that is what he called himself. His messianic task of salvation is emphasised by the addition of 'a friend of tax-collectors and sinners'. After these adjustments, Jesus and John the Baptist were no longer parallel figures; now John is the predecessor of the Messiah.

The Little Apocalypse appearing in Mark 13 came as a separate document, probably from the same church (Schmithals 1979:561, 583, 1985:400). With regards to the apocalyptic tension in the group where Q1 was circulated, Schmithals (1979:561-586) observes inter alia in Mark 13:24-27:

In those days ... the sun will be darkened and the moon will not give its light; the stars will fall from the sky and the heavenly bodies will be shaken. At that time men will see the Son of Man coming in clouds with great power and glory. He will send his angels and gather his elect from the four winds, from the ends of the earth to the ends of the heavens.

$(\mathrm{Mk} 3: 24-27)$

Schmithals (1979:582, 1994:51) holds Mark, the evangelist, responsible for the christianising of a typically apocalyptic product ending with these verses. The way that Mark does it in this passage is by identifying the Son of Man with Jesus: 'Jesus said to them: "Watch out that no one deceives you. Many will come in my Name, claiming, 'I am he' and will deceive many"' (Mk 13:5-6).

Mark indirectly criticises the apocalyptic views of the group, warning them to be watchful, seeing that the time of the end was unknown (Schmithals 1979:583): 'No-one knows about that day or hour' (Mk 13:32).

To summarise, it can be said that Schmithals succeeds in establishing an alternative to the form critical treatment of the subject matter. The originators of the form critical approach, Dibelius and Bultmann, were of the opinion that from a broad stream of kerygmatic, oral tradition a collection of paraenetic material had developed (Schmithals 1979:24, 1980:153, 1985:277, 396; cf. Bultmann 1913:24). Schmithals no longer accepts one original Christianity as bearer of the material that was handed down to flow into one broad stream of oral tradition. He adduces appropriate historical relationships in support of the literary history of the synoptic material.
Schmithals (1982a:171-172, 1985:404) finds further evidence of the existence and views of the Q1 congregation in the remarks about Apollos in Acts 18:25-26. Apollos taught very accurately about Jesus, but he was ignorant of baptism in the name of Jesus Christ. He only knew the baptism of John, which means that the cross and resurrection of Jesus had not yet become the essence of his creed. The preaching of Jesus was preached by Apollos, but not the preaching of the church of Jesus as Lord. He might have been one of the Q1 group and Priscilla and Aquilla had to instruct him in the confession of the church.

\section{The aposunagogos}

The concept of aposunagogos can be found in John 9:22, where it describes a person excluded from the synagogue: 'for already the Jews had decided that anyone who acknowledged that Jesus was the Christ would be put out of the synagogue'. To Schmithals (1985:358-359, 1987c:371:374, 1993, 1994:231) the aposunagogos became the terminus technicus for describing the exclusion of the Jewish Christians from the synagogue in the period after the destruction of the temple in $70 \mathrm{AD}$. Up to the time of the destruction of the temple, Jewish Christians enjoyed the protection given to a privileged religion in the Roman Empire. They were considered a part of Jewry. After the loss of the temple, the Pharisees reorganised Jewry, with the pharisaic interpretation of the Torah as its focal point. The Jewish-Christian church was now confronted with the law as the new focal point in the synagogue. Anyone disagreeing with this new approach had to leave the synagogue: aposunagogos. The Jewish Christians, as well as the Gentile Christians, who had been part of the synagogue as 'God fearers', could no longer remain under the sheltering roof and still uphold their creed. Consequently, they had to leave the synagogue.

The reorganisation of Jewry was also in the interest of the Roman State, because the Pharisees took a stand against the Zealot revolt and were a stabilising factor in the Jewish Diaspora. From this point of view, Jewish Christians who left the synagogue were regarded as deserters and potential rebels. The synagogue opposed these rebels and reported them to the Roman authorities. This was also in the interest of the Pharisees for their own protection. By the end of the 1st century, the curse of the heretics, Birkat-ha-Minim, had been incorporated into the daily prayer of the Jews. This represented the acme of these measures. It was an overt demonstration of the rejection of the Christians, who could no longer be considered a group within Jewry.

Schmithals (1987c:373-374, cf. 1994:240-241) even maintains that the circumstances of the aposunagogos played an important role in determining the character of the New Testament writings that were written in the period after the destruction of the temple. These books, excepting the genuine Pauline letters, comprise the whole of the New Testament. Apart from the tendency already discussed, the church had to cope with members who wanted to return to paganism under the pressure of persecution. Some rejected the authority of the government, whilst others tried to detach Christianity from its Old Testament roots. The persecution of the Jewish Christians brought them closer to the Pauline churches, given that they lived under constant threat of persecution in Nero's time, for 
example. All Christians now being outside the synagogue, the original working agreement between gentile Christians and Jewish Christians no longer made sense. Together the two groups could form the early Catholic Church.

\section{The emperor cult}

The well-known Christ hymn in Philippians 2:6-11 is seen by Schmithals (1981a:11-12, 1994:93, 1997:295-299) in the light of the worshipping of the emperor as a god. The title 'Lord' is deliberately emphasised in the confession 'Jesus Christ is Lord' at the end. The song aims at depriving the emperor of the salvific title of 'Lord'. He has a Lord above him. Jesus Christ is the 'King of kings and Lord of lords' (Rv 19:16) Furthermore, Jesus humbled himself and became human, although he was, in very nature, God. The emperor, on the other hand, delighted in being equal to God.

The Christ hymn of Philippians 2:6-11 makes Schmithals (1978:404-405, footnote 45, 1994:91-93) think of the shaping of the theological tradition of Damascus. Paul became acquainted with it at the time of his conversion. In verse 8 Paul adds the theologia crucis of the tradition of Antioch. The 'Jesus or Herod' of Matthew was written much later, in fact after the failed Jewish revolt of 66-70 AD. (Schmithals 1980c:145). 'Bethlehem or Rome' was written still later than Matthew's gospel and incorporated into his gospel by Luke (cf. Schmithals 1985:366, 375). Thus emperor worship and the tendency to equate human sovereignty with divine sovereignty constantly led to theological concepts repudiating these ideas (cf. Schmithals 1979:730).

\section{Fundamental gospel (Grundevangelium) and gospel (Evangelium)}

True to his view of the historical-critical method, Schmithals keeps to his basic rule of interpretation by examining the situation of the dialogue. Does the writer have some other concept in mind, even if he does not refer to it directly? Is there another opinion that is dismissed? Although this modus operandi is not seriously questioned and is generally accepted, when it comes from the pen of Schmithals it takes on a pregnant form. It is important to note that Schmithals improved his presentation of the matter as he progressed and modified his earlier opinions considerably in his latest publications (cf. Schmithals 1984b:116-117, 1987c:378-380). Originally, he allowed for an insignificant editing of the Gospel of John, but by making a new disposition, it appears that approximately $50 \%$ of the material used in the Gospel can be attributed to editorial adaptation. Taking as example the well-known passage of the true vine (Jn 15:1-17), Schmithals (1984b:115, 1987c:379) originally saw it against the background of the struggle between the synagogue and the church. The congregation is encouraged not to yield to the pressure of the synagogue, but to remain in the church. Later Schmithals (1992a:395) saw this text as applying to another conflict: that between the true and the false church, the conflict between the church and gnostic heresy. The true church is the one remaining in Christ and thus remaining in love and keeping the commandments.
Schmithals (1992a:219) reached the conclusion that the editor of the Grundevangelium, the evangelist, makes use of the Grundevangelium in his conflict with Docetism. His hand can be seen in the Johannine letters. He uses the language of the Grundevangelium. Whereas the point of departure in the Grundevangelium is: Jesus is the Christ, the editor could use this same statement, just giving it a different emphasis: Jesus is the Christ. In this way, he could employ it to support his own struggle. Schmithals (1992a:293-294) could dispense with a detailed analysis of Johannine grammar and linguistics because the literary contents and data supplied sufficient grounds for his assertion.

\section{The relationship between the 'proclaimer and proclaimed' as the main problem in the theological understanding of the New Testament}

Rudolf Bultmann (1979:393), in his description of the history of the synoptic tradition, came to the conclusion that the need of the early Palestinian church to vindicate itself in theological discussions led to certain writings. It collected and produced discourses in which Jesus argued with his opponents or had discussions with his disciples. The need for subject matter for teaching and the liveliness of the prophetic spirit in the church led to the production and collection of the prophetic and apocalyptic pronouncements of Jesus. The need for subject matter that could be used for reprimanding stimulated collection still further. Bultmann (1979:393) says that it was natural that stories about Jesus would be told in the church. There might have been a direct motive for the telling of stories, such as propaganda, or apologetic proof that Jesus was the Messiah. Even without any direct cause, it would have happened. Spiritual assets have a way of objectivising themselves, even without a given cause.

On the one hand, Bultmann assumes an intrinsic interest in the life and work of Jesus in the early church. On the other hand, he is well known for his opinion that Paul and John were not interested in the historical Jesus. These two points of view seem to contradict one another. The tension is produced by the fact that Paul and John do not go back to the historical Jesus, whilst the synoptic tradition does. How can one theologise with Paul and John and at the same time search for the historical Jesus? Or to put is differently, if there is a common source for the shaping of the theology of the church, how can both trends, the one being interested in the historical Jesus and the other not, be accommodated within it? Schmithals (1980d:154, cf. 1972a:66) says that he took up this matter of discrepancy in the shaping of Christological theology with Bultmann, but that Bultmann repeatedly dismissed his objection, presumably because he would not, or could not, see any problem.

Schmithals succeeded in giving a new direction to the quest. In formulating the problem, he got rid of the initial, lively interest in the historical Jesus. He pointed out that in the early church there was no great theological interest in the historical Jesus. In this respect, the tradition of Jewish Christianity did not differ from that of Hellenistic Christianity. The messianic tradition 
was accepted by the whole church. There are no historical grounds for assuming that there was, within a section of the church, the development of a return from Christ the Proclaimed to Jesus the Proclaimer. Where Jesus is understood to be an eschatological phenomenon within the church, he is never regarded as a historical phenomenon again.

If the renewed interest in the historical Jesus is not to be found in the church, this tradition must have originated elsewhere. There must have been a group, isolated from the church, which kept this tradition alive. They considered it of great importance to keep the teaching of Jesus alive, because he was a prophet, preaching the coming salvation. This group, who had heard and followed Jesus, lived in the expectation that was raised by his preaching. Schmithals thinks that it is quite likely, considering the historical evidence of a sect propagating Judaism (Ebionites), that a Jesus-community, which was still pre-Easter, existed in the time of the early church.

The widening stream of the messianic tradition of the church eliminates the probability of a return to the tradition of the historical Jesus. Because of this, the necessity of finding a theological motive for this return falls away. For the church, the line does not lead from the Proclaimer to the Proclaimed. The other remaining possibility is that the order must be reversed. Now the proclaimed Christ remains the point of departure within the church and the historical Jesus, Jesus as prophet and teacher, is added later for practical considerations.

In his commentary on the Gospel of Mark, Schmithals (1979:65-70) points out that the evangelist Mark brought the historical Jesus and the tradition of the church together. Mark's aim was to win over the Jesus sect to the church. The method that he used was to incorporate a part of the material of the Jesus tradition into his gospel. In this way he demonstrated the identity of the historical Jesus and the kerygmatic Christ Jesus. The argument Mark used for the Jesus sect was: This Jesus that you know as a prophet, whose tradition you treasure, is now the exalted Lord. In this way, the unkerygmatic Jesus tradition accidentally became part of the tradition of the church in the second or third generation of early Christianity.

Schmithals (1979:70, 1997:307-309) emphasises that it must be kept in mind that the historical Jesus tradition was used for practical reasons. It was not meant to be an independent tradition of the church, but part of the proclaiming of the kerygmatic Christ. The Jesus tradition was never fundamental to the church. The confession that Jesus is the Son of God is the foundation of Christian theology and this confession has always been the foundation of the church (Schmithals 1972b:67, 1979:66).

Schmithals was able to explain historically the problem that Bultmann saw as being the great enigma of the New Testament, the relation between the proclaiming Jesus and the proclaimed Lord of the church. Schmithals (1972b:67, 1979:66) does not regard it as an enigma. He establishes and confirms that whoever seeks the origin of the confession in Jesus Christ should not look to the very beginning or to the proclaiming Jesus, but must consider the present foundation of Christian theology, that is the proclaimed Christ.
Schmithals does not consider the finding and establishing of the proclaimed and the proclaiming Jesus to be the task of New Testament theology. New Testament theology does not begin with, or revert to the proclaiming Jesus. The origin and the present foundation of Christian theology is the confession that Jesus is the Christ. The tradition of the church and the tradition of the historical Jesus do not belong together because of an inner inevitability. The confession regarding the exalted Lord does not require to be objectified in the historical Jesus; the two traditions met accidentally.

This reconstruction by Schmithals, demonstrating that, on the whole, the early church showed no interest in the historical Jesus, compels him to identify another source of the tradition of the historical Jesus. He finds the construction by Dibelius and Bultmann that this tradition was later eliminated from the kerygmatic tradition, unconvincing (Schmithals 1980b:153). In post-Easter Christianity, memories of Jesus would not be cherished. For Paul, such memories were of as little interest as for Peter. If the early church had no interest in the historical Jesus tradition, who would have been interested?

Schmithals (1979:52-53, 1985:402-403, 1992c:142) replied that the meaning of the Easter events had not reached all the followers of the human Jesus. He identifies such an uninformed group in Galilee. They saw Jesus, together with and like John the Baptist, as a prophet predicting the coming salvation. Jesus continues the work of John the Baptist. Schmithals finds his evidence in Matthew 11:

For John came neither eating nor drinking and they say: 'He has a demon'. The Son of Man came eating and drinking and they say: 'Here is a glutton and a drunkard, a friend of tax collectors and sinners'. However, wisdom is proved right by her actions.

(Mt 11:18-19)

\section{The theological history of the New Testament}

Apart from the Old Testament, the early Christian movement also had to deal with Apocalypticism, Gnosticism and, broadly speaking, with Jewry. How did the Christian message distinguish itself from these movements and vindicate itself against their claims?

The historical method has made it clear that the Gospel cannot be proclaimed independently of the times, but must ever anew find correct understanding and expression. The one Gospel has a history in different theologies. The one Gospel is elaborated as different theologies in the canon.

\section{The relationship between the New Testament and the Old Testament}

Schmithals does not accept the salvation that came in Christ as something new, in the sense of a moment in an historical development. In Christ, a full revelation is not reached, marking everything that happened before as preliminary. There is no new revelation in Christ, but the one God, who has always been the light of humankind, reveals himself anew. The Christ event means renewal of the salvation that was always possible 
for humankind. The word that was there in the beginning and the word that became flesh are identical. The word that is now preached presents people with the newness of the Word, but it could be heard from the beginning (Schmithals 1970c:179-180, 1979:477).

\section{Eschatology and apocalypticism}

Schmithals (1988b:65) finds it advisable to distinguish clearly between the terms 'eschatology'and 'apocalyptic'. He shows the difference noticeably, by pointing out the concept of life informing in each structure. In each case the significance derives from its contrast to the other. Schmithals understands 'eschatology' to be the notion of time and life, where believing in Jesus Christ causes one to see each present time as the time of salvation open to the future. On the other hand, 'apocalyptic' does not see the present time as a time of salvation, but as a profane time (Schmithals 1973:61), although these are the last days of the Old World. The Easter faith confesses that the Christ events are eschatological saving events: 'But Christ has indeed been raised from the dead, the first fruits of those who have fallen asleep' (1 Cor 15:20). In the formula: 'so that, just as sin reigned in death, so also grace might reign through righteousness to bring eternal life through Jesus Christ, our Lord' (Rm 5:21) Schmithals (1988a:180, cf. also 1979:105) sees a breaching of the apocalyptic way of thinking. The scheme of two worlds is applied and the characteristics of both described: the reign of sin leading to death and the reign of grace leading to life. Instead of the old and new worlds, it is a matter of the old and the new human being, because the formula knows of the turning point that came in Christ. This turning point is reached in the lives of those who have received life in the midst of the world of death.

\section{Paul's theology of conversion (Damascus)}

In his historical interpretation of theology, Schmithals (1978:398-399) finds that Paul plays a part in two different theological structures. He calls attention to the tradition of the Antiochene church, on which he based his theology. On the other hand, Paul has been accused of being dependent on people instead of on the Spirit of God, so we see another theological structure coming to the fore. This structure is older than the Antiochene theology, because Paul uses it in connection with his conversion and calling as an apostle.

To be more definite about the development and localising of the Christianity to which Paul was converted, Schmithals (1978:407-410, 1982a:64, 1989:241, 1994:70) frames a hypothesis that an enthusiastic dualistic trend developed amongst the Jews of Palestine. The name of Simon Magus can be mentioned in this connection. In this gnostic Judaism, the natural and the nationalistic were sacrificed to the pneumatic. In its missionary work, Palestinian Christianity came into contact with this Jewish Gnosticism. The result was that Christian theology adopted the universalism and the accompanying freedom from the law without the dualism of the gnostic system. Substantial dualism was translated into decisive dualism. Stephen, about whom no biographical information is given in Acts, must have played a decisive role in this development.
Schmithals (1994:90) presumes that Damascus was the source of this theology. The carefully formulated ideas were typical. The prologue to the Gospel of John is a further example of the thinking and modus operandi of Damascene theology (Schmithals 1994:93-94).

\section{The theology of Antioch}

The earliest stage of the theology of Antioch is found, for example, in 1 Peter and in Paul's Antiochene formulae. The synoptic tradition represents the more recent stage of this theology (Schmithals 1984b:154).

Schmithals (1989:242-243, 1994:95, 1997:303-304) describes the Christology of Antiochene Christianity as adoptionist. According to this tradition Jesus was exalted to 'Son of God' through his resurrection. The heavenly voice saying to Jesus: 'You are my Son, whom I love' (Mk 1:9-11) speaks from the same Christological framework (Schmithals 1979:48, 85). The representation of the conception by the Holy Spirit and the virgin birth could be linked to this matter and might even replace it (Schmithals 1994:95).

In the explanation that the crucified and risen Jesus is adopted as the Son of God, the question arises of the significance of his death. Schmithals (1994:97) reaches the conclusion that the early church in Palestine interpreted it with the help of Isaiah 53. They concluded that soteriologically, he died 'for us', 'for our sins'. Several expressions indicate that this explanation became part of Antiochene soteriology (Schmithals 1994:9699). Romans 4:24b-25 serves as an example:

for us who believe in him who raised Jesus our Lord from the dead. He was delivered over to death for our sins and was raised to life for our justification.

(Rm 4:24b-25)

Add to this: 'Christ died for our sins according to the Scriptures' (1 Cor 15:3; Schmithals 1994:102-103). The church celebrating the Eucharist, 'proclaims the Lord's death' (1 Cor 11:26; Schmithals 1994:103-104).

\section{Paul's original theological ideas}

The Reformation has led us to assume that the doctrine of justification is central to Paul's theology. According to Schmithals (1978:392, 1989:251,1994:76) this complex, in reality, constitutes Paul's original theological ideas. This doctrine does not appear in all of Paul's letters, but only where he is involved in a controversy with the Jews, in the letters to the Galatians and the Romans. The doctrine comes into operation when Paul wants to organise the ecclesia apart from the synagogue (Schmithals 1988a:66, 1989:245, 1994:76, 118).

\section{Theological additions to Paul's letters by editors}

The editor who placed Paul's most important letters at the disposal of all the churches at the time of the aposunagogos dissociated the church from the turbulent Jews (1 Th 2:1416). Unlike them, the church remained loyal to the Roman authorities (Rm 13:1-7). 
The editor of the secondary collection of Pauline letters (Colossians, Ephesians and Philemon) also worked against the background of the aposunagogos. He did his best to urge the gentile Christians of the Pauline churches to welcome Jewish Christians in their midst, who had dissociated themselves from the synagogue at the same time that the moral rules of the synagogue were impressed upon them.

\section{Ethics}

Ethical decision-making has largely been transferred to the political field since World War II. Political problems are the subject of discussion in church. Sermons and pastoral messages all make an attempt at giving guidance in political matters. The political responsibility of Christians and the church is highlighted from all angles. In his reflections on ethics, Schmithals concentrates largely on the actuality of politics. Consequently, it is important to have a closer look at his approach to ethics as far as politics are concerned. The priority lent to political problems does not detract from his discussion of ethics in general, because the basic principles for ethical conduct are the same, whether on a social or personal level.

\section{The church and the Christian}

The church has received the command to proclaim the gospel (Schmithals 1970a:36, 42, 1979:324-325, 1983d:131). In practice, the church has to preach. By the work of the church, salvation is brought to people and they are reconciled to God. This commission of the church is linked to church office and office bearers. Schmithals feels that it is a good arrangement that official meetings of the church and office bearers should not take sides in political issues of the day. This is because office bearers are obliged to proclaim the gospel to all members of the congregation, regardless of their political convictions (Schmithals 1983d:125).

Schmithals' point of view is not fully understood in a party political context. He did not mean that party politics divided the people and that church meetings and office bearers should therefore abstain from it. His reticence regarding politics goes much deeper. Schmithals is not concerned only about party politics, but about all politics. In the Old Testament, God's people and the people of the state were identical. As a result the prophets were also political prophets. Israel could not easily maintain this self-concept, because the prophets contradicted one another and each claimed that he was proclaiming the truth. In the New Testament, this ambivalence is avoided by breaking up the unity between the people of the state and God's people. Each individual becomes a member of the congregation. The church does not see itself as being of political importance, but as the Kingdom of God, clearly distinguishable from the kingdoms of the world. Political prophecies, where the office bearer or bearers express their opinions on current political questions, wish to identify God's people with people of the state once more. This has always been rejected as sectarian by the church (Schmithals 1983a:1819; 1983c:73, 1983e:147-148, 1983f). This sectarian tendency is seen in Rautenbach (1978:78-79), where he recommends political prophecy. He calls it 'prophetic enlightenment of the political order by means of preaching, confession, witness, pastoral letters, messages from the pulpit, et cetera'. This can only result in justifying political behaviour on the strength of the gospel. The prophetic office of the church can have no other content but the proclamation of the Christ-event. After Jesus Christ there is no room for another prophet (Schmithals 1983a:19).

The differentiation between people of the state and God's people is often seen as being typically Lutheran. In contrast, we have the reformed view, in which the sovereignty of Christ also includes the people of the state. Schmithals (1983a:17-18) disagrees. He does not feel that the socio-ethical application of the sovereignty of Christ reflects the true reformed point of view. The Heidelberg Cathecism would sooner formulate the Lutheran point of view as being Jesus Christ 'reigns by Word and Spirit' over God's people. All efforts to justify political action Christologically are thus thwarted. Schmithals (1983a:15-16, 1983d:127) states that Barth eventually also engaged in finding a christological basis for political action.

According to Schmithals (1983c:73, 1983e:149, 1986a:33), the church should not attempt to present some or other political opinion with prophetic authority. On the one hand, it is the church's task to proclaim the message of the forgiveness of $\sin$. That is what the world needs to hear from the church. No one else brings these tidings. On the other hand, political problems are solved by suggestions, which are acceptable to both Christians and non-Christians. These suggestions cannot have the status of infallible truth. The best way of dealing with such suggestions is to assess them in daily practice, with the realisation that it will not be the end of problems and perplexities. The most suitable answer to these suggestions is not that this is a dependable word, as one says concerning the gospel. Referring to himself, Schmithals (1986a:33) says that as a teacher and in his ministry, he refrains from presenting his own political insight or, worse still, holding it up as being Christian. In his office he is expected to keep his political views to himself. As a matter of principle, he does not participate in voting when official meetings assume the right to give political advice or make binding demands on people in authority or on ordinary citizens. These suggestions could even correspond to his own views. However, he has his political point of view as a citizen and as a Christian, but not as a minister of the Word. As citizen and Christian, Bonhoeffer took part in the plot against Hitler (Schmithals 1983a:21).

The reticence shown by Schmithals concerning political problems of the day must not be seen as an attempt, on his part, to escape responsibility. On the contrary, it is because of his insight into the nature of the gospel and his respect for the people listening to the sermon. They should not be overwhelmed and frustrated to the extent that the congregation becomes a pressure group. This cannot be the political service rendered to the world by the church. The church has a more profound task.

Where there is no clear distinction between the authority of the church to proclaim the gospel and the political maturity of the members of the church, there will continually be problems. When official meetings make political pronouncements, it 
casts doubt on the political maturity of the members. This position becomes untenable and unintentionally it is admitted in the statement, 'the members of the church will have to exert themselves seriously to keep hearing the voice of Christ in the official pronouncements of the church' (Nederlandse Hervormde Kerk 1965:31; NHK).

It will undoubtedly be contended that members of the church do not display political maturity. Such a judgement can be made on the strength of a particular political persuasion, in terms of which anyone who holds a different opinion is politically immature. In any case, Schmithals says, the church is not going to develop political maturity in its members by teaching them politics. Independent people are only freed for politics by the preaching of the gospel.

By means of the political diaconate (not political prophecy, cf. Schmithals 1983 a:22) the church liberates Christians to accept their worldly political responsibility (Schmithals 1970a:39, 1972c:123-124, 1979:129, 1983a:21, 1983c:72, 1986a:33). In the world, the believers serve mankind, life and humanity, but not parties and ideologies. Humanity is served, not because mankind is the ultimate value, making politics sacred, but because the Christian conserves faith in love. Believers cannot but be politically involved. They have the courage to participate in politics, because their plans need not be perfect, as though coming from God (cf. van Wyk 1987:410). Their intentions are not what God would intend. Even if their plans go wrong, the world is still in God's hand. Therefore, they can act as they see fit. Believers know that the kingdom within which they perform their deeds of charity is not the Kingdom of God. It is not even a forerunner of God's Kingdom and this knowledge prevents them from becoming presumptuous. They build houses with walls that crack. Theirs is not the work of salvation. They disagree with the statement of the Nederlandse Hervormde Kerk 'that politics have to do with truth and justice which belong to the kingdom of God'(NHK 1965:39). Pilate's question: 'What is truth?' (Jn 18:38) is the acknowledgement that he, being a politician, has nothing to do with truth and justice. Truth and justice belong to the kingdom that is not of this world (Schmithals 1980c:150-151).

At the time of the celebration of the 750 years of existence of Berlin, Schmithals, himself a Berliner, delivered a sermon on Jeremiah 29:7: 'if it (the city) prospers, you too will prosper'(Schmithals 1987a). What will be best for the city? What we think? Perhaps, but it could also be what others think. Therefore, it is advisable to listen to one another and look at the interests of the city from all angles. People are not all the same and everyone would like to do things differently. On the same piece of land, one person would like to build a house, another a hospital and a third an Old Age Home. On one side of the wall, there is the onslaught on the human spirit by capitalism. On the other communist propaganda prescribes what is right. Neither of these two serves the best interests of the city. The different interests will have to be combined. Concessions are in the interest of the city. This applies to larger interest groups as well as to the individual. Although it might be necessary to make demands on others, it is still not the best. The best would be for each to do his duty.
Schmithals feels that it would be a good thing if the wall were to disappear, so that one Berliner is not shot by another. However, he realises that the unity of the city will not be achieved easily. Therefore, the Berliners must use openings that exist in the wall to the best of their ability. The text in Jeremiah 29:7 continues: 'Pray to the Lord for it (the city)'. Further on it becomes clear that Schmithals understands Christian faith as providing man with the strength to live in conflict. The prayer for the city makes us realise that humans are powerless and that our cities are not in our hands. Prayer places the city in God's hands. At the same time it gives thanks for a habitable city where God also has his own people. It is best for any city to have people meeting in it who are on their way to the eternal city. They toil tirelessly for the progress and welfare of this transient city, always keeping the eternal one in mind.

According to Schmithals (1970a:40-41), preaching the gospel with a view to liberating Christians to become politically active in the social-ethical field merely communicates opinions. It is not preaching of the gospel unless it can be accepted as such by people who hold different views. Any opinions expressed must not have an assertive colour, but should rather be tentative. Accompanying commentary might be 'If I am not mistaken' or 'In this I am not covered by the authority of God's word' (cf. Schmithals 1983b:49, 55).

Another example of an opinion expressed by Schmithals (1983b:49-56) on the political course of events, has to do with peace. Schmithals distinguishes between the peace given by God, which passes all understanding and the peace that must be maintained amongst people to the best of their political knowledge. The peace that is a gift from God gives the believer the impartiality to work for peace amongst men. In this service he will not be surpassed by anyone. The difference between the peace of God and political peace is important. The peace of God is independent of the degree of political peace that has been achieved. Political peace, which depends on move and countermove, can never be maintained without risk and apprehension (Schmithals 1980c:135).

Schmithals (1983b:51) points out that some people try to establish political peace by means of mutual trust, whilst others use deterrents. He denies that trust and reconciliation will be more peaceful and Christian, in the given human condition, than suspicion and mutual control. What is best in a particular set of circumstance will have to be settled in fear and trembling; there is no Christian demand that can be made. Could one in all fairness expect the communists to trust the system of the West or vice versa? We would all prefer to live without armament, but the superpowers arm themselves to survive. Peace in the world is armed peace (Schmithals 1983b:53).

To preach the peace of God is the mandate that the church has received. This peace consists in the justification of sinners. In spite of all man's burdens and the risks that he runs, he may know that he is borne up by God. This is the solace within which a Christian lives and this is how he serves peace. The constant admonition of the New Testament 'to live in peace with everybody' is just as appropriate today. Christians must 
build mutual trust, despite political differences (Schmithals 1983b:54-55, 1983c:74-75).

Schmithals (1972c:141-142) warns people not to misunderstand him. Although one is unsure of the correct thing to do in each case, Christians must be admonished, as brothers, to accept the world. It is the place where faith must be lived to the full and be conserved to make itself serviceable in love. We have no choice as to whether these ethical questions should be asked and answered. We are in the midst of this reality. It goes without saying that specific ethical norms and customs will be followed. This does not imply obedience to these norms and customs, but rather the obedience of faith, which is prepared even to oppose accepted values.

On the one hand, the preaching of the gospel liberates people for their service to the world. On the other, a political sermon can assume a second form, when direct political utterances amount to proclaiming the gospel. It happens when, for example, the statement that Christianity must be defended with military force is contradicted. This very contradiction is, in fact, preaching of the gospel (Schmithals 1970a:40).

Although the church does not see itself as a sociological or political body, it might, on occasion, be necessary to speak on behalf of disenfranchised people (Schmithals 1970a:38, 1983a:21-22). It could, in different ways, be necessary in Eastern Bloc states and South Africa (Schmithals 1986a). However, Schmithals immediately adds that the Church must not overestimate its aid to the oppressed. This could be a hindrance to the Christians in the given circumstances and render them immature (Schmithals 1970a:38, cf. 1983a:22). The idea is that Christians should join groups, which can help to promote the welfare of these people. Here they operate with others in a worldly fashion and argue on factual grounds. There are no Christian prescriptions (Schmithals 1972c:124). The peace of the world is served as mundanely as possible. The Christian aims at righteousness and welfare for all, in short, a better world, together with other people. Moreover, Schmithals (1975:3) does not base this on Christ's direct sovereignty over the world or the social involvement of the Church in the world, because the improved world will always wait upon further improvement. The peace that Christians bring into the world is peace as the world gives it (Schmithals 1983c:77). Schmithals (1975:3) bases the Christian's striving for a better world in a profane manner. He asks: What else would Christians strive for?

\section{Creature and creation}

In Schmithals' dealings with the world, one cannot speak of a 'theology of nature' (Buitendag 1986:693-694; cf. Engelbrecht 1988:25). There can be no direct route from the basic doctrine of dual order to the theology of social problems. In the same way, no direct theological pronouncement can be made concerning nature conservation. Christians who are involved in

conservation are being led by their intellect. The word 'nature' is no theological term; the wonder and gratitude to God that binds people to creation are missing. There is a tendency to concentrate on endangered nature, rather than on creation. As Buitendag formulates it: 'what is necessary is a doctrine that unites God, man and non-human creatures to such an extent that exploitation would be impossible'. In a meditation on a psalm concerning creation, Psalm 104, Schmithals (1987b) admits that it is difficult to ignore man's disruption of nature, but that we should not suppress the wonder and gratitude for creation in our hearts. The way in which we associate with creation depends on the stand we take: are we opposed to nature or are we in the midst of the created world, dependent on God?

In the midst of the created world, believers, being guilty, sigh together with creation. They know that the world suffers more from the good intentions than from the evil intentions of humankind. However, guilt does not have the last word. The sighing makes present to the believer the promise of a lost salvation restored (Schmithals 1986b).

From this exposition it becomes clear that the eco-ethic of Schmithals is also ethics of situation based on eschatology. Creation is not equated with the new creation (Schmithals 1981b:218); the new creation shares in the grace that man receives. As far as the situation is concerned, Schmithals (1983b:49) fears that the attention given to the environment distracts the attention from a greater need, namely that nations should make political peace. Not only nature, but life itself, is threatened by political conflict. Not only creation, but history too, is threatened by humankind.

\section{Conclusion}

The present theology is not really conversant with the theology of Bultmann. Despite the fact that he is generally considered the outstanding authority on the New Testament in our age, it is surprising how negligible the factual knowledge of his work remains. There are few authorities on and students of his work.

This state of affairs can be traced to the misunderstanding of the trend of his theology. It was already apparent in the Bultmann school. He complains about the misunderstanding of his view of the main problem of New Testament theology for example. Referring specifically to his gifted student Ernst Käsemann, he says, 'O Absalom, mein Sohn, mein Sohn!' [Oh Absalom, my son, my son!] (in Schmithals 1968:kol 262). If these misunderstandings were to continue, it would only be to the detriment of New Testament science. Schmithals must be given credit for the fact that he did justice to the theological intent of his tutor. He did not disregard the old problems, but considered them lucidly. This is what his work claims to be and his contribution must be judged accordingly. I know of no one who acquitted himself better of this task than Schmithals. This is what it is really all about: the thorough grasp of the Biblical reformational theology by means of the historical criticism. The true meaning of this method has never been as thoroughly examined as was done by Schmithals. 


\section{References}

Boers, H., 1979, What is New Testament theology? The rise of criticism and the problem of the New Testament, Guides to Biblical scholarship: New Testament Series, Fortress, Philadelphia.

Buitendag, J., 1986, 'Die skepping as gelykenis: 'n Beoordeling van die skeppingsleer van Karl Barth in die lig van die appèl van die ekologiese krisis', HTS Teologiese Studies/ Theological Studdies 42, 674-695.

Bultmann, R., 1913, 'Was lässt die Spruchquelle über die Urgemeinde erkennen?', Oldenburgisches Kirchenblatt 19(7), 35-37; 19(8), 41-44.

Bultmann, R., 1950, Leistungs-Zeugnis zur Bewerbung um Gebürenerlass für stud. theol. Walter Schmithals. Unpublished.

Bultmann, R., 1954, Referat über die Dissertation des Pfarrers W Schmithals 'Die Gnosis in Korinth'. Unpublished.

Bultmann, R., 1967, Brief an die theologische Arbeitsgemeinschaft Philipps Haus, Marburg an der Lahn in Protokoll der Tagung 'Alter Marburger', 3. -6. Januar 1983 Marburg an der Lahn, in Protokoll der Tagung Alter Marbur
und 2. -5. Januar 1984 in Hofgeismar, 32-33. Unpublished.

Bultmann, R., [1925] 1975, Das Problem einer theologische Exegese des Neuen Testaments, in Strecker, G (Hrsg), Das Problem der Theologie des Neuen Testaments, pp. 249-277, WdF, CCCLXVII, Darmstadt: Wissenschaftliche Buchgesellschaft.

Bultmann, R., [1921] 1979, Die Geschichte der synoptische Tradition, 9 Aufl., Vandenhoeck, Göttingen.

Cadbury, H.J., 1933, 'The Hellenists', in F.J. Foakes Jackson \& D.D. Kirsopp Lake (eds.), The beginnings of Christianity, Part I, vol. v, pp. 59-73, Macmillan, London.

Engelbrecht, B.J., [1962] 1982, 'Wat is die reg en die vryheid van die eksegeet?', in Versamelde opstelle, deel 2, pp. 51-67, Universiteit van Pretoria, Pretoria.

Engelbrecth, B.J., 1988, 'Teologie en ekologie', HTS Teologiese Studies/Theological Studies 44, 23-38.

Nederlandse Hervormde Kerk. Generale Synode, 1965, De politieke verantwoordelijkheid van de kerk, 2de druk, Boeckencentrum, 'S-Gravenhage.

Rautenbach, C.H., 1978, 'Die toekoms van die kerk in die samelewing: Kollig op die sosiaal-etiese, insluitende politieke afmetings van Christelike kerk-bly in Suid-Afrika', in W.S. Vorster (ed.), Church and society/Kerk ensamelewing, pp. 68-97, Unisa, Pretoria.

Schmithals, W., 1953, 'Die Bekehrung des Zachäus: Lk 19, 1-10', RKZ 24, 534-536.

Schmithals, W., 1965, Paulus und die Gnostiker: Untersuchungen zu den kleinen Paulusbriefen, Reich, Hamburg-Bergstedt.

Schmithals, W., 1965a, 'Die Häretiker in Galatien', in Schmithals 1965:9-46.

Schmithals, W., 1965b, Die Irrlehrer von Rom. 16, 17-20, in Schmithals 1965:159-174.

Schmithals, W., [1966] 1967a, Die Theologie Rudolf Bultmanns: Eine Einfürung 2, durchgesehene Aufl., Mohr, Tübingen.

Schmithals, W., 1967b, 'Zur gegenwärtigen Predigtnot und ihrer Überwindung', KiZ 3, $94-102$.

Schmithals, W., 1968, 'R Bultmann, Glauben und Verstehen: Gesammelte Aufsätze IV', ThLZ 93(4), kol 260-262.

Schmithals, W., [1956] 1969, Die Gnosis in Korinth: Eine Untersuchung zu den Korintherbriefen. 3., bearbeitete und ergänzte Aufl., FRLANT NF 48, Vandenhoeck, Göttingen.

Schmithals, W., 1970a, Das Christuszeugnis in der heutigen Gesellschaft: Zur gegenwärtigen Krise von Theologie und Kirche EZS 53, Reich, Hamburg

Schmithals, W.,1970b, 'Sinn und Aufgabe der modernen Theologie', Die Spur 3, 80-85.

Schmithals, W., 1970c, 'Die Frage nach Gott im Neuen Testament', Die Spur 5, 176-185.

Schmithals, W., 1971a, Vernuft und Gehorsam: Zur Standortbestimmung der Theologie, EZS 58, Reich, Hamburg.

Schmithals, W.,1971b, 'Barth, Bultmann und wir: Zum Methodenproblem in der Theologie', EZS 59(60), 49-64.

Schmithals, W.,1972, Jesus Christus in der Verkündigung der Kirche: Aktuelle Beiträge zum notwendigen Streit um Jesus, Neukirchener Verlag, Neukirchen-Vluyn.

Schmithals, W., [1962] 1972a, Paulus und der 'historische' Jesus, in Schmithals 1972:36-

Schmithals, W., [1970] 1972b, Das Bekenntnis zu Jesus Christus, in Schmithals 1972:60-

Schmithals, W., [1971] 1972c, Politische Theologie, in Schmithals 1972:118-143.

Schmithals, W., [1970] 1972d, Erwägungen zur Didaktik des Theologiestudiums, in Schmithals 1972:187-205.

Schmithals, W., 1973, Die Apokalyptik: Einführung und Deutung, Vandenhoeck, Göttingen.

Schmithals, W., 1974, 'Theologie - Hochschule - Wissenschaft', RKZ 8, 82-84.

Schmithals, W., 1975, 'Abkehr vom Wahn der Machbarkeit: Gedanken zum Busstag, Der Tagesspiegel Berlin, 19 November, p. 3.

Schmithals, W., 1976, 'Andacht über Mt 28, 18-20', in Protokoll Bd 1 der Verlautbarungen der Regionalen Synode der Ev Kirche in Berlin-Brandenburg (Berlin-W.), pp. 145-148, Manuscript.

Schmithals, W., 1978, 'Zur Herkunft der gnostische Elemente in der Sprache des Paulus', in B. Aland (Hrsg.), Gnosis, pp. 385-414, Vandenhoeck, Göttingen.

Schmithals, W.,1979, Das Evangelium nach Markus, 2 Bde., ÖTK2/1; 2/2; GTB-Siebenstern 502; 503, Mohn, Gütersloh.
Schmithals, W., 1980a, Das Evangelium nach Lukas, ZBK NT 3.1., Theologischer Verlag, Zürich.

Schmithals, W., 1980b, Die theologische Anthropologie des Paulus: Auslegung van Röm 7,17 - 8,39, Urban-Taschenbuucher/ Kohlhammer Taschenbuucher 1021, Kohlhammer, Stuttgart.

Schmithals, W. \& Gunneweg, A.H.J., 1980c, Herrschaft, Kohlhammer Taschenbücher Biblische Konfrontationen, 1012, Kohlhammer, Stuttgart.

Schmithals, W., 1980d, 'Kritik der Formkritik' in ZThK 77, 149-195.

Schmithals, W., 1981a, 'Herrschaft und Sorge', EPD Dokumentation 30, 10-18.

Schmithals, W., 1981b, 'Meditation zu Lk 24, 36-45', GPM 35, 213-218.

Schmithals, W., 1982a, Die Apostelgeschichte des Lukas, ZBK NT 3.2., Theologischer Verlag, Zürich.

Schmithals, W., 1982b, Auslegungen von 1. Kor 2, 1-10, in Protokoll der Tagung 'Alter Marburger', 2. -5. Januar 1981 und 4. -7. Januar 1982 in Hofgeismar, 68-82.

Schmithals, W., 1982c, s.v. 'Evangelien, synoptische', TRE.

Schmithals, W., 1983, Bekenntnis und Gewissen: Theologische Studien zur Ethik. Zum 60. Geburtstag herausgegeben von Hess, H-E \& Wildemann B., CZV-Verlag, Berlin.

Schmithals, W., [1980] 1983a, 'Aufgaben und Grenzen einer christlichen Ethik des Politischen', in Schmithals 1983:12-24

Schmithals, W., [1981] 1983b, 'Theologische und ethische Überlegungen zum Problem des Friedens', in Schmithals 1983:40-56.

Schmithals, W., [1982] 1983c, 'Zum Friedensauftrag der Kirche und der Christen', in Schmithals 1983:57-77.

Schmithals, W., [1982] 1983d, 'Politische Äusserungen der Kirche und ihrer Amtsträger', in Schmithals 1983:125-134.

Schmithals, W., 1983e, 'Das Bekenntnis der Gemeinde und das Gewissen der Christen', in Schmithals 1983:139-153.

Schmithals, W., 1983f, J'eremia 8, 4-7', in Anregungen zur Predigt am Volkstrauertag 1983 , hrsg. von VDK, Hessen Druck, Kassel.

Schmithals, W., 1984a, Die Briefe des Paulus in ihrer ursprüngliche Form, Zürche Werkkommentare zur Bibel, Theologischer Verlag, Zürich.

Schmithals, W., 1984b, Neues Testament und Gnosis, Wissenschaftliche Buchgesellschaft, Erträge der Forschung; Bd. 208, Darmstadt.

Schmithals, W.1985, Einleitung in die drei ersten Evangelien, De Gruyter Lehrbuch, De Gruyter, Berlin.

Schmithals, W.,1986a, 'Politisches Handeln verträgt kein Amen', Der Tagesspiege 19.11.1986, 33.

Schmithals, W., 1986b, 'Römer 8, 18-27 (28)', in Anregungen zur Predigt am Volkstrauertag 1986, 1986, 11-15, hrsg. von V.D.K., Ahrend Inh, Baunatal.

Schmithals, W.,1987a, Berliner Rundfunkpredigt: 'Suchet der Stadt Bestes', 26. April 1987. Ev. Rundfunkdienst in der Berliner Arbeitsgemeinschaft für Kirchliche Publizistik.

Schmithals, W., 1987b, 'Psalm 104, 24', Gemeindebrief der Lindenkirche, 10.87.

Schmithals, W., 1987c, 'Der Konflikt zwischen Kirche und Synagoge in neutestamentlicher Zeit, in', in M.J. Oeming \& A. Graupner (Hrsg.), Altes Testament und christliche Verkündigung: Festschrift für Antonius H J Gunneweg zum 65. Geburtstag, pp. 366-386, Kohlhammer, Stuttgart.

Schmithals, W., 1988a, Der Römerbrief: Ein Kommentar, Mohn, Gütersloh.

Schmithals, W., 1988b, 'Eschatologie und Apokaliptik', VuF 33(1), 64-82.

Schmithals, W., 1989, 'Paulus als Heidenmissionar und das Problem seiner theologischen Entwicklung', in D.-A. Koch, G. Sellin \& A. Lindemann (Hrsg.), Jesu Rede von Gott und ihre Nachgeschichte im fruhen Christentum: Beiträge zur Verkündigung Jesu und zum Kerygma der Kirche: Festschrift für Willi Marxen zum 70. Geburtstag, pp. 235-251, Mohn, Güterloh.

Schmithals, W.,1992a, Johannesevangelium und Johannesbriefe: Forschungsgeschichte und Analyse, BZNW 64, De Gruyter, Berlin. doi:10.1515/9783110857153

Schmithals, W.,1992b, 'Das Alte Testament als hermeneutische Problem', in In memoriam Antonius H.J. Gunneweg, pp. 9-25, Alma Mater 76, Bouvier, Bonn.

Schmithals, W.,1992c, 'Die Bedeutung der Evangelien in der Theologiegeschichte bis zur Kanonbildung', in F. Van Segbroeck et al. (Hrsg.), The Four Gospels 1992: Festschrift Frans Neirynck, University Press, Leuven.

Schmithals, W.,1993, 'Das Verhältnis von Juden und Christen in neutestamentlicher Zeit', Treffpunkt Matthäus, Evangelisches Gemeindeblatt der Matthäusgemeinde 'Zeit', Treffpunkt

Schmithals, W., 1994, Theologiegeschichte des Urchristentums: Eine problemgeschichtliche Darstellung, Kohlhammer, Stuttgart.

Schmithals, W., 1996, 'Zu Karl Barths Schriftauslegung: Die Problematik des Verhältnisses von 'dogmatischer' und historischer Exegese', in M. Trowitzsch (Hgrs.), Karls Barth Schriftauslegung, Mohr, Tübinger.

Schmithals, W., 1997, 'Vom Ursprung der synoptischen Tradition', ZThK 94(3), 288-316.

Schmithals, W., 2001, Die Evangelisten als Schriftsteller, Theologischer Verlag, Zürich.

Schmithals, W., 2008, 'Das Messiasgeheimnis und die Spruchquelle', HTS Teologiese Studies/Theological Studies 64(1), 353-375.

Van Wyk, I.W.C., 1987, 'Das Theodizeeproblem als Orientierungspunkt der Kirchenpolitischen und theologischen Streitfragen: Eine Auseinandersetzung mit ürgen Moltmann', DD dissertation, University of Pretoria. 